\title{
Biofortified High Zinc Wheat: The Traditional Staple Dietary Food to Address Malnutrition in Pakistan
}

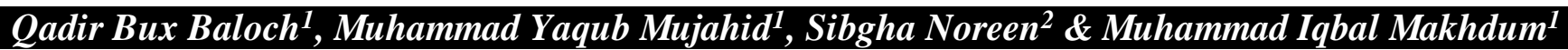

${ }^{1}$ HarvestPlus Pakistan, National Agricultural Research Center, Park Road, Islamabad

${ }^{2}$ Institute of Pure \& Applied Biology, Bahauddin Zakariya University, Multan, Pakistan

Corresponding Author Email: drmimakhdum@yahoo.com

Received 25/2/2018; Accepted 21/3/2018; Published 31/3/2018

\section{Abstract}

Background: The footprints of zinc dietary nutrient deficiency are resulting in a widespread burden of stunting, wasting and underweight in children under five years, and reproductive development in women over a population of 100 million in Pakistan. The zinc malnutrition could be addressed by consumption of biofortified high zinc wheat flour, a staple food, in complemented with food supplementation, food diversification and food fortification interventions in the country.

Methodology: This evidence-based research publication focused on micronutrients malnutrition on human health and capital. Literature was taken from last 20 years papers published in several peers reviewed scientific journals. Papers regarding malnutrition were mainly focused. The primary data was collected from R\&D institutions and secondary data from Pakistan National Nutrition Survey 2011. Various sites, viz. www.harvestplus.org, www.ifpri.org, http://www.ars.usda.gov/ba/bhnrc/ndl, http://data.unicef.org: www.fao.org: http://wholibdoc.who.int/publications were also visited.

Results: In Pakistan, the recently released biofortified high zinc wheat variety "Zincol-2016" had a higher quantum of $37 \mathrm{mg} \mathrm{Zn} \mathrm{kg}^{-1}$ compared to $25.0 \mathrm{mg} \mathrm{Zn} \mathrm{kg}^{-1}$ in grain portion in other commercially grown wheat varieties. Upon consuming biofortified wheat flour, zinc concentration increased from 681.3 to $792.3 \mu \mathrm{g} \mathrm{L} \mathrm{L}^{-1}$ in human plasma. Furthermore, even an increase in dietary zinc by an amount of $2.0 \mathrm{mg} \mathrm{Zn} \mathrm{capita}{ }^{-1} \mathrm{day}^{-1} \mathrm{may}$ result in halving the endemic problem of zinc malnutrition, with a little change in food diversity pattern.

Conclusion: The consumption of biofortified high zinc wheat variety "Zincol-2016" containing $37 \mathrm{mg} \mathrm{Zn} \mathrm{kg}$ ${ }^{1}$ compared to $25.0 \mathrm{mg} \mathrm{Zn} \mathrm{kg}{ }^{-1}$ in conventional wheat varieties could result in alleviating zinc malnutrition to the extent of $50 \%$ in the malnourished population. Thereby, it is a potential complementary staple food with other contemporary interventions to address malnutrition in Pakistan.

\section{Keywords}

Zinc Malnutrition, biofortified wheat, micronutrient deficiency syndrome, zinc nutritious food

\section{Introduction}

At the global level, more than two billion people are experiencing a syndrome of malnutrition ${ }^{1}$, and a greater proportion of households to be affected by $2050^{2}$. Considering the alarming situation, various international and national organizations under Charter of Sustainable Development Goals (SDGs) [Goal-2 (Zero Hunger) and Goal-3 (Good Health and Wellbeing)] have stepped their efforts to address malnutrition ${ }^{3}, 4$. The earliest three years (1000 days) starting from the day of conception, lays foundation stone for enjoying a goodness of health and a little attention for the feeding of nonnutritious diet either to expecting mothers or later to babies beyond two years, would cause an irreversible loss to one's healthiness, mental and physical development ${ }^{5}$. Among the risk factors, the poor diet is a major determinant, which afflicts the human health to a greater degree than any other component ${ }^{6}$. Among other developing economies, more than 100 million inhabitants of Pakistan are living apart from nutritious diet, as to lead a healthy life style ${ }^{7}$. The strategy to address malnutrition includes food supplementation, food diversification, 
food fortification and biofortification of staple food crops. Among these interventions, the consumption of biofortified staple foods has shown their potential in not only being cost-effective and available at space and time; but also reducing disease burden in terms of DALYs (Disability Adjusted Life Years) ${ }^{8,}$ 9 . The agriculture sector leverages the production of food not only in higher quantity but also nutritious too. However, a little attention was given to the production of nutritious food following Green Revolution $\mathrm{Era}^{4,7,10,11}$. The greater accessibility to diversified food products coming from agriculture sector would address the under-nutrition problem $^{12}$, 13,14

\section{The extent of Malnutrition:}

The micronutrients deficiency, termed as 'malnutrition' and/or 'hidden hunger' is a widespread phenomenon in under-nutrition population, living in developing economies ${ }^{15}, 16$. The burden of malnutrition in terms of stunting, wasting and under-weight is inversely correlated with an outcome of dietary diversity at home ${ }^{15,16}$. At the global level, one-third of people are facing a different degree of malnutrition ${ }^{17}$. However, more than $50 \%$ of the malnourished community will fall prey to this uncertainty if not efforts are undertaken by the world community ${ }^{17}$. Apart from this, onethird of the world population is facing the burden of obesity ${ }^{13}$. Among these, $50 \%$ children under 5 years of age are facing deficiencies of micronutrients ${ }^{5}$. The nutritious food produces a far greater impact on first 1000 days in one's life, therefore, it needs greater attention ${ }^{18}$. At present, more than 100 million populations are facing deficiency syndrome due to deficiency of micronutrient, dietary nutrients viz., iron, zinc, vitamin $\mathrm{A}$ and $\mathrm{D}$ to the extent of $61.9 \%, 39.2 \%, 54.0 \%$ and $40.0 \%$; respectively ${ }^{19}$. Among the nutrients, $47.6 \%$ women and 39.2\% children under 5 years age are burdened with deficiency syndrome of zinc ${ }^{19}$. The deficiency of zinc reduces the production process in women and physical development in children ${ }^{1}$. The diarrheal disease is also associated with zinc deficiency ${ }^{20}$. The long-run persistence of malnutrition is impacting heavy economic toll on the economic growth and development of the country. The economic loss accounts for US\$ 7.6 billion annually, equal to $3.0 \%$ of GDP per annum. The zinc deficiency causes a loss of US\$ 770 million per annum $^{2}$. The workforce is facing the loss of US\$ 2.24 billion per annum. In the year 2010, 0.323 million out of 182 million people were lost with respect to disability-adjusted life years (DALYs) in Pakistan $^{21}$. The toll stood to 187 DALYs out of 0.1 million people. There are estimates that the DALYs toll of 0.173 million in Punjab and 0.071 million in Sindh provinces ${ }^{21}$. This loss could be saved by consuming biofortified high zinc wheat, without any additional $\operatorname{cost}^{22}$. In terms of DALYs, the reduction could vary from 0.5 to $37 \%$ by consuming biofortified wheat ${ }^{22}$. The biofortified wheat as a complementary food and/or substituting it with conventional wheat would serve for providing nutritious diet as to overcome the malnutrition in a large population in accordance with WHO goals ${ }^{23}$.

\section{Nutrition-Health Nexus:}

The malnutrition burdens a number of noncommunicable diseases (NCDs), viz., diabetes, cardiovascular disease, cancer, stroke stress which could be alleviated through nutritious food ${ }^{16}$. The consumption of biofortified wheat would serve as nutrition-specific intervention along with other nutritious food and/or who solely subsists on cerealbased $\operatorname{diet}^{13}$. Zinc element is a crucial nutrient to carry out numerous physiological and biochemical processes in the humans ${ }^{24}$. It is involved in growth and development, immune and reproductive functions and 1000 enzymatic networks ${ }^{25}$. The occurrence of dwarfism during adolescence in the Middle East was due to deficiency of zinc nutrient ${ }^{26}$. The human body has a little storage capacity for zinc nutrient contrary to iron and vitamins $21,27$. Therefore, the body derives its daily requirement from the diet. There are evidence that restricted mental and physical development is closely associated with deficiency of zinc nutrient ${ }^{7}, 28,29$. There are estimates that resource-poor households subsisting on cereal-based diet and consuming little amount of vegetables and fruits are highly prone to NCDs $^{30}$. In Pakistan, wheat is a staple food, which 
is consumed by the amount of $390 \mathrm{~g} \mathrm{capita}^{-1}$ day $^{-1}$ 31. Despite its heavy consumption, the zinc nutrient derived from consuming wheat flour is not sufficient to meet the daily requirement. The reason being that cereal diet i.e., wheat, rice, maize, and barley have a lower quantity of zinc. Moreover, cultivation of cereals on soils which are severely deficient in nutrients further caused a reduction in zinc content in grains ${ }^{32}$. The content of zinc in grain varies from $19-30 \mathrm{mg} \mathrm{Zn} \mathrm{kg}{ }^{-1}$ in commercial cultivated wheat varieties. Whereas, the human body requires double of this quantity to satisfy the human needs. Moreover, the wheat grains contain a greater amount of phytic acid, which -chelates the zinc nutrient, thus its bioavailability is reduced ${ }^{33}$. Bioavailability of zinc dietary nutrient is reduced due to the existence of phytic acid, and zinc -chelate compounds are formed ${ }^{34}$. The bioavailability could be increased by the presence of higher amounts of amino acids in the diet and/or from animal products $^{35}$. There was higher rate of bioavailability of zinc nutrient from biofortified wheat compared to conventional wheat ${ }^{36}$, resulting in improvement in dietary zinc derived from biofortified wheat 37 . Currently, the amount of zinc content in biofortified wheat variety Zincol-2016 is $37 \mathrm{mg} \mathrm{Zn} \mathrm{kg}^{-1}{ }^{38}$. The higher amount of grain resulted in enhancing the level of zinc in blood plasma to meet the physiological need of the body ${ }^{37}$. Studies have revealed that intake of zinc was higher from biofortified wheat compared to non-biofortified wheat which resulted in higher absorption by the body ${ }^{36,38}$.

\section{Interventions to Address Malnutrition:}

During the Green Revolution Era in the 1960s, much attention was given to increase the productivity of staple food crops to ensure food security, however, nutrition security received a little attention since then ${ }^{39,40}$. The cereals contain a low amount of micronutrients and further growing them on potentially micronutrient deficient soils resulted in a widespread deficiency of micronutrients in humans ${ }^{41}$. In the contemporary world, the ubiquitous problem of malnutrition is being addressed through these interventions. a) Food Supplementation: The clinical treatment by dispensing multi-vitamins compounds, vaccination, vitamin A pills.

(b) Food Fortification: The food products are mechanically fortified with the addition of iron, folic acid, zinc, vitamin A and D and iodine in wheat flour, milk products, vegetable oil and table salt, respectively. The accessibility of these products is limited in the low-income rural areas. In the developing economies, it has achieved a little success due to poor marketing system and coverage of the large population.

(c) Food Diversification: The majority of the population subsists on cereal-based diet and enjoys a little liberty to eat vegetables, fruits, and meat products. Wheat is consumed by the quantity of 390 g capita $^{-1}$ day $^{-1}$, while rice at a distant second having a quantity of $37 \mathrm{~g} \mathrm{capita}^{-1}$ day $^{-1}{ }^{10}$. Moreover, wheat provides $60 \%$ of calories followed by $12 \%$ and $10 \%$ from oil and sugar products ${ }^{10}$. The extent of the population to the tune of $83.4 \%, 70.8 \%, 67.4 \%$ and $65.6 \%$ living in Balochistan, Sindh, Khyber Pakhtunkhwa and Punjab, respectively who cannot buy nutritious food to improve their health ${ }^{10}$. There is evidence that consuming soft drinks, sugar and processed food have a little nutritional value and also expensive ones. The practicing of kitchen gardening and consuming naturally grown wild fruits would be valuable ${ }^{42}$.

(d) Biofortification: The biofortification of staple food crops has been considered a recent strategy to address maladies of micronutrient malnutrition ${ }^{43}$. In the realm of agriculture for nutrition, biofortified crops offer their best services to meet dietary nutrients. Various researchers reported production of biofortified wheat staple food crop is the most cost efficient and can be cultivated over time and space in different ecologies 8,43 .

The footprints of micronutrients malnutrition are visible among 100 million inhabitants living in the peri-urban and rural areas. The households have a 
little purchasing power to buy nutritious food, i.e., vegetables, fruits and meat products. The contemporary interventions i.e., food supplementation, food diversification, food fortification have been found to be a little access to the target population (www.harvestplus.org). Moreover, these measures require heavy human and capital investment on a long-term basis. Thereby, a strategy is ought to be apt, which could be more cost-effective, affordable and having a greater accessibility to the malnourished households. There is a need for development of varieties of staple food crops which contain inherently higher quantum of dietary nutrients in their genetic background without any extraneous addition during processing of food, as to meet the micronutrient deficiency needs of the humans. Targeting this objective, a number of biofortified varieties of staple food crops viz., wheat, rice, maize, pearl millet, beans, potato, sweet potato, and cassava are being developed with the higher quantum of nutrient traits i.e., zinc, iron and vitamin $\mathrm{A}$ in their genetic background and transgressed through classical genetic manipulation. As an effort to address malnutrition, the introduction of biofortified high zinc wheat varieties would prove a valuable intervention to satisfy the micronutrients thirst of the human body. The enriching staple food crops through genetic manipulation is called 'Biofortification'. Crops are biofortified by addition of one or more essential nutrients to the seed of staple food crops through plant breeding technique. The germplasm stacked with higher nutrient traits are cross-bred with high yielding crop varieties, as to make them more nutritious over the current ones, without compromising the yield potential ${ }^{44,} 45,46$. Currently, commercially grown wheat varieties contain zinc content on an average of $25 \mathrm{mg} \mathrm{Zn} \mathrm{kg} \mathrm{zg}^{-1}$ (ranging from 19.0 to $30.0 \mathrm{mg} \mathrm{Zn} \mathrm{kg}^{-1}$ ) in grains, whereas this amount has to be raised by 50 percent higher than the current level of the nutrient.

\section{Methodology}

The research and development work for the development of biofortified high zinc wheat varieties with the collaboration of HarvestPlus has been going on at federal and provincial wheat research institutes across the country since 2003. Under the umbrella of National Agricultural Research System, the research on genetic manipulation to develop highly zinc nutritious wheat varieties is being undertaken by the National Agricultural Research Center, Islamabad; Wheat Research Institute, Faisalabad; Wheat Research Institute, Sakrand; Cereal Crops Research Institute, Pir Sabak; and Agricultural Research Institute, Quetta. The cooperation has been extended by Consultative Group for International Agricultural Research (CGIAR), International Maize \& Wheat Improvement Center (CIMMYT), Federal and Provincial Governments of Pakistan, proved highly enumerative in furthering the development of biofortified wheat (www.harvestplus.org).

\section{Results}

The research efforts made by Wheat $R \& D$ Institutions resulted in the development of $1^{\text {st }}$ wave high zinc wheat variety in the year 2016. The biofortified high zinc wheat variety 'Zincol-2016' has been introduced for production and consumption. The variety has a comparable productivity and contains $37 \mathrm{mg} \mathrm{Zn} \mathrm{kg}{ }^{-1}$ (+12 baseline) in grain, i.e., $50 \%$ higher zinc content over conventional wheat varieties and well-adapted in different ecologies. Apart from it, the variety is also rich in mineral constituents i.e., iron (67 to 85), calcium (284-382), phosphorus (3137-4203) and potassium (4105-5433) $\mathrm{mg} \mathrm{kg}^{-1}$ in the grain portion. During the last two the years 2016-2018, 65 tons of biofortified wheat seed Zincol-2016 was distributed among 2600 (male 1400, female 1200) small landholding farming families under World Vision Canada's ENRICH Project 'Enhancing Nutrition Services to Improve Maternal and Child Health in Africa and Asia" in district Sukkur, Sindh province. Moreover, 2400 tons seed was disseminated among farmers and seed multipliers for massive production in various provinces. The farmers had been sensitized about the health benefits, as to reduce the prevalence of mental and physical impediments. The biofortified wheat is particularly more valuable for small farming households, low-income people 
who are living far-flung settlements in the rural $\operatorname{areas}^{47}$.

In Pakistan, consumption of wheat is $390 \mathrm{~g}$ capita $^{-1}$ day $^{-1}$, on the other hand, rice is $37 \mathrm{~g} \mathrm{capita}^{-1}$ day $^{-1} 48$. The currently grown wheat varieties contain an amount of $23.9 \mathrm{mg} \mathrm{Zn} \mathrm{kg}{ }^{-1}{ }^{49}$, out of which, $7.1 \mathrm{mg}$ Zn capita $^{-1}$ day $^{-1}$ becomes available to human body $^{50}$. On the other hand, estimated average requirement (EAR) is $10.4 \mathrm{mg} \mathrm{Zn} \mathrm{capita}{ }^{-1}$ day $^{-1}{ }^{48}$. The consumption of biofortified staple food which is nutritious one would be a potential option for reducing hidden hunger in the rural populations ${ }^{37}$. The amount of zinc content in wheat grains could be enhanced by practicing application of zinc fertilizer either through the soil and/or foliar ${ }^{51}$. The poor households spend 53-60\% of the total expenditure on food products. Of the total Of the total US\$ 1.0,US\$0.50 (PKR 50) per day per adult equivalent expenditure, the purchase for food and non-food accounts for US\$ 0.30 (PKR 30) and US\$ 0.20 (PKR 20) per day respectively. The livelihood of the poor is skewed towards a narrow range of foods, which limits bringing of food diversity, to ward off the ill effects of deficiencies of micronutrients ${ }^{52,53}$. The bioavailability of zinc dietary nutrient could be enhanced by "the measures; wheat flour may be leavened with yeast, leafy vegetables and fruits may be consumed, biofortified high zinc wheat flour may be consumed, take multivitamin/mineral supplements on the prescription of physician, most of the multivitamins/mineral supplements provide sufficient quantity.

In a recent study, the consumption of wheat flour by $330 \mathrm{~g} \mathrm{capita}^{-1}$ day $^{-1}$, would provide daily intake of $8.6 \mathrm{mg}$ zinc capita $^{-1}$ day $^{-1}$, as compared to the daily intake of $11 \mathrm{mg}$ zinc capita ${ }^{-1}$ day $^{-1}{ }^{20}$. Thereby, a greater proportion of the population is undernutrition because of the presence of phytic acid in cereal grains. The average daily zinc dietary intake was recommended as $9 \mathrm{mg}$ zinc capita ${ }^{-1} \mathrm{day}^{-1}$ for women and $13 \mathrm{mg}$ zinc capita ${ }^{-1} \mathrm{day}^{-1}$ for $\mathrm{men}^{54}$. The increase in dietary zinc by the amount of $2.0 \mathrm{mg} \mathrm{Zn}$ capita $^{-1}$ day $^{-1}$ may result in reducing the endemic problem of malnutrition by about $50 \%$ with a little change in food dietary pattern ${ }^{20}$. The addition of 4 mg Zn day ${ }^{-1}$ in dietary food caused improvement in serum protein and repairing DNA (deoxyribonucleic acid) strands ${ }^{55}$. The significant increase of zinc concentration was recorded from 681.3 to $792.3 \mu \mathrm{g} \mathrm{L}^{-1}$ in human plasma zinc by consuming biofortified wheat flour ${ }^{38}$. Furthermore, the bioavailability of zinc dietary nutrient (the amount which body derives from the dietary food), is relatively high in meat products, eggs, legumes, and nuts; because of greater availability of amino acids viz., cysteine and methionine ${ }^{56}$. The bioavailability of zinc nutrient is reduced due to the higher content of phytic acid in the cereal grain products $^{57}$. Consumption of biofortified wheat could be augmented by consuming various food items (Table 1).

Table 1: Food Sources of Zinc Nutrient

\begin{tabular}{lc}
\hline Food & Zinc Nutrient(mg/kg) \\
\hline Sesame seed & 78 \\
\hline Beef, cooked & 60 \\
\hline Sorghum Bread & 60 \\
\hline Rye (Whole grain flour) & 56 \\
\hline Mint (Mentha longifolia) & 51 \\
\hline Goat Meat & 45 \\
\hline Oat (Whole grain flour) & 39 \\
\hline Cabbage & 38 \\
\hline Taro (Arvi, Arum) (Colocusia esculenta) & 32 \\
\hline Chicken Egg Yolk (raw) & 31 \\
\hline
\end{tabular}




\begin{tabular}{ll}
\hline Sugar Brown (Jaggery) & 29 \\
\hline Wheat (Whole grain flour) & 29 \\
\hline Barley (Whole grain flour) & 20 \\
\hline Tomatoes & 20 \\
\hline Beans, baked & 18 \\
\hline Chicken, cooked & 18 \\
\hline Milk & 18 \\
\hline Yogurt, fruit & 18 \\
\hline Proso millet (Panicum miliaecum $)$ & 17 \\
\hline Chickpeas, cooked & 13 \\
\hline Almonds & 10 \\
\hline Cheese & 9 \\
\hline Peanuts & 9 \\
\hline
\end{tabular}

\section{Future Prospects}

Biofortified high zinc wheat is a nutrition-specific intervention to alleviate the public health problem. This is a complementary intervention along with other dietary foods to reduce micronutrient-ind uced ailments in under -nourished population. In the year 2017, HarvestPlus Pakistan reached to 80, 000 farming households with biofortified wheat seed. For three years now in 2020, the biofortified wheat seed will capture a share of $1.5 \%$ of the total wheat seed market. In the years to come, about 4.8 million households living in the rural areas will be deriving health benefits by consuming biofortified wheat in the country.

\section{Conclusion}

The endemic persistence of malnutrition is ought to be addressed through multi-dimensional aspects. In complement with other interventions to reduce malnutrition, the consumption of biofortified high zinc wheat variety "Zincol-2016" containing more than $50 \%$ zinc content compared to conventional wheat varieties is a potential option to reduce the zinc malnutrition in Pakistan. The consumption of biofortified wheat among the rural population would result in halving the zinc malnutrition through regular intake of biofortified wheat.

\section{Conflicts of Interest}

None.

\section{Acknowledgment}

The study was supported by HarvestPlus (www.harvestplus.org). The authors are grateful to scientists of National Agricultural Research System (NARS) for carrying out R\&D works in biofortification of wheat crop in Pakistan.

\section{Funding}

None.

\section{References}

1. Black R. Micronutrient deficiency: an underlying cause of morbidity and mortality. Bull World Health Org; 2003; 81:79.

2. Bagriansky J. Economic Consequences of Undernutrition in Pakistan. World Food Program. 2017.

3. Stuart L. Transforming Our World: The 2030 Agenda for Sustainable Development A/RES/70/1: THEME: statement, 'Do not leave Indigenous Australians behind'.

4. Haddad L, Hawkes C, Webb P, Thomas S, Beddington J, Waage J, Flynn D. A new global research agenda for food. Nature News. 2016; 540(7631):30.

5. Aguayo VM, Menon P. Stop stunting: Improving child feeding, women's nutrition and household sanitation in South Asia. Maternal \& child nutrition. 2016; 12(S1):3-11.

6. Kraemer K, Cordaro JB, Fanzo J, Gibney M, Kennedy E, Labrique A, Steffen J, Eggersdorfer M. .3 Managing Value Chains for Improved Nutrition. In Good Nutrition: Perspectives for the 21st Century 2016; 45-59. Karger Publishers.

7. Malik S, Nazli H, Mehmood A, Shahzad A. Issues in the measurement and construction of the consumer 
price index in Pakistan. Intl Food Policy Res Inst; 2014.

8. Stein AJ, Nestel P, Meenakshi JV, Qaim M, Sachdev HP, Bhutta ZA. Plant breeding to control zinc deficiency in India: how cost-effective is biofortification? Public health nutrition. 2007; 10(5):492-501.

9. Stein AJ. Rethinking the measurement of undernutrition in a broader health context: Should we look at possible causes or actual effects? Global Food Security. 2014; 3(3):193-9.

10. Malik SJ, Nazli H, Whitney E. Food consumption patterns and implications for poverty reduction in Pakistan. Pakistan Development Review. 2015; 54(4):651-70.

11. Hawkes C, Ruel MT. Value chains for nutrition. Reshaping Agriculture for Nutrition and Health. IFPRI. 2012: 73-82.

12. Diets S. Biodiversity-Directions and solutions for policy, research and actions [website]. Rome: Food and Agriculture Organization of the UN. 2012.

13. HLPE. Nutrition and Food Systems: A report by the High Level Panel of Experts on Food Security and Nutrition of the Committee on World Food Security, Rome. 2017.

14. Bégin F, Aguayo VM. First foods: Why improving young children's diets matter. Maternal \& child nutrition. 2017; 13(S2).

15. Chandrasekhar S, Aguayo VM, Krishna V, Nair R. Household food insecurity and children's dietary diversity and nutrition in India. Evidence from the comprehensive nutrition survey in Maharashtra. Maternal \& child nutrition. 2017; 13(S2).

16. Hawkesworth S, Dangour AD, Johnston D, Lock K, Poole N, Rushton J, Uauy R, Waage J. Feeding the w orld healthily: the challenge of measuring the effects of agriculture on health. Philosophical transactions of the royal society B: Biological sciences. 2010; 365(1554):3083-97.

17. Bégin F, Aguayo VM. First foods: Why improving young children's diets matter. Maternal \& child nutrition. 2017; 13(S2).

18. White JM, Bégin F, Kumapley R, Murray C, Krasevec J. Complementary feeding practices: Current global and regional estimates. Maternal \& child nutrition. 2017; 13(S2).

19. National Nutrition Survey (NNS). National Nutrition Survey of Pakistan, Ministry of Planning, Development and Reform, Government of Pakistan, Islamabad. 2011.

20. Joy EJ, Ahmad W, Zia MH, Kumssa DB, Young SD, Ander EL, et al. valuing increased zinc ( $\mathrm{Zn}$ ) fertiliseruse in Pakistan. Plant and Soil. 2017;411(1-2):139-50.
21. Wessells KR, Brown KH. Estimating the global prevalence of zinc deficiency: results based on zinc availability in national food supplies and the prevalence of stunting. PloS one. 2012; 7(11):e50568.

22. Lim SS, Vos T, Flaxman AD, Danaei G, Shibuya K, Adair-Rohani H, AlMazroa MA, Amann M, Anderson $\mathrm{HR}$, Andrews KG, Aryee M. A comparative risk assessment of burden of disease and injury attributable to 67 risk factors and risk factor clusters in 21 regions, 1990-2010: a systematic analysis for the Global Burden of Disease Study 2010. The lancet. 2012; 380(9859):2224-60.

23. World Health Organization of the United Nations (WHO). Macro-nutrients and Health: Investing in Health for Economic Development. Report of the Commission on Macro-economics and Health World Health Organization. Geneva. 2001; p 31.

24. Broadley MR, White PJ, Hammond JP, Zelko I, Lux A. Zinc in plants. New Phytol. 2007; 173(4):677-702.

25. Cousins PD, Handfield RB, Lawson B, Petersen KJ. Creating supply chain relational capital: the impact of formal and informal socialization processes. J Oper Manag. 2006; 24 (6):851-63.

26. Prasad AS, Halsted JA, Nadimi M. Syndrome of iron deficiency anemia, hepatosplenomegaly, hypogonadism, dwarfism and geophagia. Am J Med. 1961; 31(4):532-46.

27. Wessells KR, Jorgensen JM, Hess SY, Woodhouse LR, Peerson JM, Brown KH. Plasma Zinc Concentration Responds Rapidly to the Initiation and Discontinuation of Short-Term Zinc Supplementation in Healthy Men. J Nutr. 2010; 140(12):2128-33.

28. von Grebmer K, Saltzman A, Birol E, Wiesman D, Prasai N, Yin S, et al. Global Hunger Index: The challenge of hidden hunger. IFPRI books. 2014.

29. Black RE, Allen LH, Bhutta ZA, Caulfield LE, De Onis M, Ezzati $M$, et al. Maternal and child undernutrition: global and regional exposures and health consequences. The Lancet. 2008; 371 (9608):243-60.

30. Zaki SA, Chaaban J, Nasreddine L, Chalak A. The impact of food price increases on nutrient intake in Lebanon. Agric Food Eco. 2014; 2(1):3.

31. Agricultural Statistics of Pakistan. Ministry of National Food Security and Research, Government of Pakistan, Islamabad. 2016.

32. Zou C, Zhang Y, Rashid A, Ram H, Savasli E, Arisoy $\mathrm{R}$, et al. Biofortification of wheat with zinc through zinc fertilization in seven countries. Plant Soil. 2012; 361(1-2):119-30.

33. Akhtar S. Malnutrition in South Asia-A critical reappraisal. Crit Rev Food Sci Nutr. 2016; 56(14):2320-30. 
34. Gibson RS, Yeudall F, Drost N, Mtitimuni B, Cullinan T. Dietary interventions to prevent zinc deficiency. Am J Clin Nutr. 1998; 68(2):484S-7S.

35. Turnlund J, King J, Keyes W, Gong B, Michel M. A stable isotope study of zinc absorption in young men: effects of phytate and a-cellulose. Am J Clin Nutr. 1984; 40(5):1071-7.

36. Donangelo CM, Woodhouse LR, King SM, Toffolo G, Shames DM, Viteri FE, et al. Iron and zinc absorption from two bean (Phaseolus vulgaris L.) genotypes in young women. J Agric Food Chem. 2003; 51(17):5137-43.

37. Rosado JL, Hambidge KM, Miller LV, Garcia OP, Westcott J, Gonzalez K, et al. The quantity of zinc absorbed from wheat in adult women is enhanced by biofortification. J Nutr. 2009; 139(10):1920-5.

38. Khan MJ, Ullah U, Usama N, Broadley M, Afridi MZ, Zia M, McArdle HJ, Young S. Effect of agronomically biofortified zinc flour on zinc and selenium status in resource poor settings; a randomised control Trial. In proceedings of the Nutrition Society 2017 Jan 1 (Vol. 76, No. OCE 4, Pp. E183-E183). Edinburgh Bldg, Shaftesbury Rd, Cb2 8ru Cambridge, England: Cambridge Univ Press.

39. Remans R, Wood SA, Saha N, Anderman TL, DeFries RS. Measuring nutritional diversity of national food supplies. Global Food Security. 2014; 3(3-4):174-82.

40. Khoury CK, Jarvis A. The changing composition of the global diet: Implications for CGIAR research. CIAT Policy Brief. 2014(18):6.

41. Bouis HE, Hotz C, McClafferty B, Meenakshi JV, Pfeiffer WH. Biofortification: a new tool to reduce micronutrient malnutrition. Food and Nutrition Bulletin. 2011; 32(1_suppl1):S31-40.

42. Hawkes C, Ruel MT. From agriculture to nutrition: Pathways, synergies and outcomes.2008.

43. Bouis H, Low J, McEwan M, Tanumihardjo S. Biofortification: evidence and lessons learned linking agriculture and nutrition. The Food and Agriculture Organization of the United Nations (FAO) and the World Health Organization (WHO). 2013.

44. Bouis HE, Welch RM. Biofortification - a sustainable agricultural strategy for reducing micronutrient malnutrition in the global south. Crop Science. 2010; 50(Supplement_1):S-20.

45. Saltzman A, Birol E, Bouis HE, Boy E, De Moura FF, Islam Y, et al. Biofortification: progress tow ard a more nourishing future. Global Food Security. 2013; 2(1):917.

46. Nestel P, Bouis HE, Meenakshi J, Pfeiffer W. Biofortific ation of staple food crops. J Nutr. 2006; 136 (4):1064-7.
47. Ronoh A, Were G, Mueni M. Biofortified Crops Can Alleviate Micronutrient Deficiencies: Review of Evidence from Randomized Feeding Trials. Vitam Miner 2017.6:154.

48. Kumssa DB, Joy EJ, Ander EL, Watts MJ, Young SD, Walker S, Broadley MR. Dietary calcium and zinc deficiency risks are decreasing but remain prevalent. Scientific reports. 2015; 5:10974.

49. Joy EJ, Ahmad W, Zia MH, Kumssa DB, Young SD, Ander EL, Watts MJ, Stein AJ, Broadley MR. Valuing increased zinc $(\mathrm{Zn})$ fertiliser-use in Pakistan. Plant and soil. 2017; 411(1-2):139-50.

50. United States Department of Agriculture (USDA). National nutrient database for standard reference. 2013. Release 26, available online: http://www.ars.usda.gov/ba/bhnrc/ndl.

51. Meenakshi J, Johnson NL, Manyong VM, DeGroote $\mathrm{H}$, Javelosa J, Yanggen DR, et al. How cost-effective is biofortification in combating micronutrient malnutrition? An ex ante assessment. World Dev. 2010; 38(1):64-75.

52. Arif GM, Nazir S, Satti MN, Farooq S. Child malnutrition in Pakistan: Trends and determinants. Pak Inst Dev Econ. 2012.

53. Di Cesare M, Bhatti Z, Soofi SB, Fortunato L, Ezzati M, Bhutta ZA. Geographical and socioeconomic inequalities in women and children's nutritional status in Pakistan in 2011: an analysis of data from a nationally representative survey. The Lancet Global Health. 2015; 3(4):e229-e39.

54. Food and Nutrition Board, Institute of Medicine. Zinc In: Dietary Reference Intakes for Vitamin A, Vitamin $\mathrm{K}$, Boron, Chromium, Copper, Iodine, Iron, Manganese, Molybdenum, Nickel, Silicon, Vanadium and Zinc. Washington, DC. National Academy Press, 2001; 442-501.

55. Zyba SJ, Shenvi SV, Killilea DW, Holland TC, Kim $\mathrm{E}$, Moy A, et al. A moderate increase in dietary zinc reduces DNA strand breaks in leukocytes and alters plasma proteins without changing plasma zinc concentrations. Am J Clin Nutr. 2016; 105(2):343-51.

56. Higdon J. An evidence-based approach to vitamins and minerals health benefits and intake recommendations: Thieme Medical Publishers, Inc.; 2003.

57. King, J.C., R.J. Cousins. Zinc. In: Shils, M.E., Shike, M., Ross, A.C., Caballero, B. Cousins, R.J. eds. Modern Nutrition in Health and Disease. $10^{\text {th }}$ ed. Baltimore, MD, Lippinc ott Williams \& Wilkins, 2006; 271-285 